\title{
The Idea of Reading in Early Twentieth Century South Africa
}

Corinne Sandwith

University of Pretoria, South Africa

Early twentieth century South Africa saw the emergence of a range of liberal reading initiatives aimed at encouraging a black reading culture. What ensued was a lively public debate about reading and the uses of the book which included not only the liberalphilanthropic groups that gave support to these projects but also those African readers and intellectuals who found themselves the targets of the reading initiative itself. In the first part of this paper, I highlight the prominent role played by liberal advocates of the book in establishing the broad parameters of the book reading encounter in South Africa, particularly as it related to emergent black reading communities. I give attention to the nature of this developing reading consensus and the assumptions about reading and the world of the book that it encoded. In the second part of the paper, I explore the ways in which this consensus was negotiated by African readers and intellectuals. To this end, I look at some of the traces and fragments of an on-going debate about reading and its social and personal value which is recorded in the contemporary African press. The aim of the paper is not only to ascertain how Africans responded to the liberal incitement to read but also to address some of the contestations over the meaning and use-value of reading during this period as part of a more general history of reading in early twentieth-century South Africa.

The reading habits of particular readers and reading communities in history - what books were read, where they were consumed and the ways in which they were valued and interpreted - continues to exert a particular fascination for historians of the book. ${ }^{1}$ This inquiry raises several methodological questions, including not only how common readers might be recovered from 'the vast silence which has swallowed up most of mankind's

\footnotetext{
${ }^{1}$ A few examples from a wealth of scholarship include, Robert Altick, The English Common Reader (Chicago, University of Chicago Press, 1957); Jonathan Rose, The Intellectual Life of the Working Classes (New Haven, CT, Yale University Press, 2001); Elizabeth McHenry, Forgotton Readers: Recovering the History of African American Literary Societies (Durham, Duke University Press, 2002); Stephanie Newell Literary Culture in Colonial Ghana: 'How to Play the Game of Life' (Manchester, Manchester University Press, 2002); William St. Clair, The Reading Nation in the Romantic Period (Cambridge, Cambridge University Press, 2004); Martyn Lyons, A History of Reading and Writing in the Western World (Basingstoke, Palgrave Macmillan, 2010) and Archie L. Dick, The Hidden History of South Africa's Book and Reading Cultures (Pietermaritzburg, University of KwaZulu-Natal Press, 2013).
} 
thinking, ${ }^{2}$ but also how to assess the relative weight, value and veracity of the various 'documents of reading' that are available. Scholars such as Martyn Lyons have insisted on the importance of historicising the encounter between the reader and the book, ${ }^{3}$ an approach which highlights both the 'habits and the habitus' of reading. ${ }^{4}$ In order to ascertain the particular quality of reading experiences in specific historical periods, I argue, it is also important to establish a sense of the prevailing 'reading consensus', an idea that foregrounds the range of already-existing, a priori assumptions about the meaning and value of reading which circulate in the public sphere. The idea of a reading consensus points to the set of assumptions (always tenuous in their ideological reach) that establish the terms in which reading takes place and which exert an influence on individual book encounters and the processes of meaning-making that ensue. To place emphasis on the reading consensus therefore is to explore the specific discursive environments that reading falls into and the ideological contexts that give it shape.

Archie L. Dick's recent study of the hidden histories of book and reading cultures in South Africa deploys a similar conceptualisation, one which places emphasis on the spatial-material aspects of the reading and book encounter. Dick's 'zones of influence', a concept that draws on De Certeau's distinction between 'strategy' and 'tactic', foregrounds the way in which particular institutions of reading (missions, libraries and schools) attempt to exert an influence on reading habits by defining appropriate reading matter and authorising acceptable reading practices, contexts and styles. Forms of institutional authority such as the mission and the school, argues Dick, exist in perpetual tension with the assumptions and practices of actual readers who adopt a variety of 'tactical', improvisational and alternative reading strategies as part of the ongoing 'struggle for reading'. 5

Early twentieth-century South Africa presents a particularly over-determined context for an inquiry into the prevailing reading consensus, one which is both written over and underwritten by a number of competing concerns. The dense overlay of assumptions about the relationship between race and reading in particular are worth noting, not least because of the complexities of the ideological context, one which encompassed both energetic

\footnotetext{
${ }^{2}$ Robert Darnton, 'Intellectual and Cultural History' in Michael Kammen (ed) The Past Before Us: Contemporary Historical Writing in the United States (Ithaca, Cornell University Press, 1980), p.343.

${ }^{3}$ Lyons, A History of Reading and Writing in the Western World (Basingstoke, Palgrave Macmillan, 2010).

${ }^{4}$ Katie Halsey and W.R. Owens (eds), Introduction to The History of Reading Volume 2: Evidence from the British Isles c1750-1950 (Basingstoke, Palgrave McMillan, 2011), p.1.

${ }^{5}$ Archie L. Dick, The Hidden History of South Africa's Book and Reading Cultures, pp. 4-6.
} 
proscriptions on 'non-European' reading from the conservative right as well as a range of liberal reading initiatives inspired by the idea of Western civility. Adding further texture to an already complex discursive environment were the views of those intellectuals and activists associated with the South African Left, a loose political grouping which also placed great store on the importance of reading and the efficacy of the book. In these intellectual circuits, the idea of reading finds traction as part of a broader project of social and political emancipation; here, reading is variously construed as a means of instruction and political emancipation and as a creative 'commons' for political polemic, action and critique. ${ }^{6}$

The 1930s and 40s saw a steady commentary and a range of discussions in the public domain concerning the social and personal merits of book reading. This was the consequence of several efforts across the country to provide library services for black South Africans who were barred from municipal libraries under the prevailing segregationist laws. ${ }^{7}$ Participants in this discussion included not only the many librarians, missionaries and educators who were closely associated with, and gave support to, the 'non-European' library initiatives but also those African readers and intellectuals who found themselves the targets of the liberal reading initiative itself. For the scholar of reading, this presents an especially productive moment for an investigation into historical reading practices and assumptions in South Africa, a moment in which prevailing attitudes towards reading are being articulated in particularly explicit ways. The evidence of these reading debates, I suggest, points to the especially prominent role played by liberal advocates of the book in establishing the broad parameters of the book reading encounter in South Africa, particularly as these relate to an emergent black reading culture and black reading communities.

Early articulations of the twentieth-century reading question in South Africa tended to be confined to the linked reading communities associated with white-sponsored, black-edited

\footnotetext{
${ }^{6}$ See Corinne Sandwith, World of Letters: Reading Communities and Cultural Debates in Early Apartheid South Africa (Pietermaritzburg, University of KwaZulu-Natal Press, 2014).

${ }^{7}$ For histories of black library services in South Africa, see Marguerite A. Peters, The Contribution of the Carnegie Non-European Library Service Transvaal to the Development of Library Services for Africans in South Africa: An Historical and Evaluative Study, (Pretoria, State Library, 1975); Tim Couzens, The New African: A Study of the Life and Work of H.I.E. Dhlomo (Johannesburg, Ravan, 1985), pp. 101, 198; Alan G. Cobley, 'Literacy, Libraries, and Consciousness: The Provision of Library Services for Blacks in South Africa in the PreApartheid Era', Libraries and Culture 32, 1 (1997), pp. 57-80; Maxine Rochester, 'The Carnegie Corporation and South Africa: Non-European Library Services', Libraries and Culture, 34,1 (1999), pp. 27-51. For details of more ad-hoc or piece-meal efforts to establish libraries for black readers, see Alan Cobley, 'Literacy, Libraries, and Consciousness'. For a history of library developments in the Western Cape in particular, see Patricia Clarke, "'Better Libraries for Everyone!": The Development of Library Services in the Western Cape in the 1940s', Innovation, 28 (2004), pp. 22-30.
} 
papers such as The Bantu World, Umteteli wa Bantu and Ilanga lase Natal and as well as some of the publications arising out of the work of the missions such as The Good Shepherd and The South African Outlook. This has partly to do with the fact that commercial, whiteowned newspapers and other liberal forums had themselves been co-opted into the liberal welfare project and thus served as an additional platform in the broader national initiative to inspire people to read. Evidence for this receptivity (and ideological congruence) is to be found in the regular articles that appeared in the commercial African press in particular on reading and its benefits as well as the numerous reports that were published on the progress of the 'Non-European' library movement and the success of its projects. Apart from acting as vectors for the views of white liberals, these newspapers - which had wide circulation and significant readerships - also provided a forum for members of, a largely urban, African elite whose various responses in the form of letters and articles represent a significant intervention in the reading debates of the period.

By far the greatest concentration of articles on reading and the world of the book are to be found in The Bantu World, a popular national newspaper launched in 1932 which represented a loose coalition of white commercial (later mining) and liberal-elitist interests. Another significant forum for the reading debate, and one which tended towards a more contestatory political stance was Inkundla ya Bantu, a Durban-based publication which was also the only independent, African-owned newspaper in existence at the time. ${ }^{8}$ Taking these two publications as representative of the general debate - and making brief forays into another Durban-based newspaper, Ilanga lase Natal, I explore the influence of the liberal reading consensus on the idea of reading amongst African readers as well as the various ways in which it was negotiated, adopted and tactically undermined.

\section{The Book in the Location}

Tim Couzens elucidates the particular social and historical contexts which provided the impetus for liberal reading initiatives in early segregationist South Africa in his study of the life and work of South African poet and playwright H.I.E. Dhlomo. Couzens identifies the influence of transatlantic connections, in particular the success of reading projects in the rural American South in encouraging particular forms of political decorum in the post-Civil War period. Tied to these was the stimulus provided by black American intellectuals such as

\footnotetext{
${ }^{8}$ I conducted a manual search of microfilm versions of these papers, concentrating specifically on the 19301945 period.
} 
Booker T. Washington and James Aggrey and the emphasis they placed on self-help and inter-racial co-operation. Developments in the South African social context were also significant, specifically the perceived threat posed by rapid, unregulated urbanisation, the growth of 'slums' and increasing black political agitation. ${ }^{9}$ As Deborah Posel has argued, it was the threat posed by the anarchic and infectious African 'location' which prompted an intensifying engagement with the idea of urban African welfarism and the notion of the welfare state. ${ }^{10}$ Also significant during this period was the establishment of organisations such as the Joint Council Movement, the Bantu Men's Social Centre and the Gamma Sigma Club which placed emphasis on inter-racial collaboration and the role of culture as a powerful ameliorative and moralising force. ${ }^{11}$

The work of one of the foremost library initiatives in the county, the Carnegie non-European Library in Johannesburg, was explicitly framed in these terms. Annual reports suggest a construction of libraries and reading as important components of moralised leisure and a mitigating force against both hooliganism and political dissent. Of interest here is the way in which progressive library initiatives are framed as a form of 'intellectual welfare' - thus situating libraries alongside other projects of social uplift such as housing and public health. ${ }^{12}$ Arguments highlighting the moral uses of 'non-European' libraries tended to be written with a strong awareness of the unregulated and anarchic location space; in particular, they placed emphasis on the resonance of the book in the 'location' - of the spectacle of the threatening township space magically transformed through the power and panacea of the book. ${ }^{13}$ In this context, the 'book' and the 'location' are established as antagonistic elements in the broader social field. These assumptions are not unique to the racialized context of early segregationist South Africa. As Lewis Roberts has argued, the importance placed on, or the hopes invested in, the pedagogic effects of reading - practises which would produce not only knowledge but

\footnotetext{
${ }^{9}$ Couzens 'The New African', pp. 82-93.

${ }^{10}$ Deborah Posel, 'The Case for a Welfare State: Poverty and Politics of the Urban African Family in the 1930s and 40s', in Saul Dubow and Alan Jeeves (eds), South Africa's 1940s: A World of Possibilities (Cape Town, Double Storey Books, 2005), pp. 64-76.

${ }^{11}$ For details, see Couzens, The New African, pp. 93-114

${ }^{12}$ Carnegie Non-European Library, Transvaal: First Report (National Library of South Africa, Pretoria, 1935), p. 2.

${ }^{13}$ For an important discussion on the book as 'fetish' in the nineteenth-century context, see Isabel Hofmeyr, The Portable Bunyan: A Transnational History of The Pilgrim's Progress (Johannesburg, Wits University Press, 2004), pp. 72-75.
} 
the habits of sobriety, decorum and diligence - was also central to early nineteenth century arguments for the establishment of Free Libraries in Britain. ${ }^{14}$

Also influential in framing the assumptions of liberal library projects in South Africa was the ideology of the Joint Council movement and its emphasis on the promotion of reciprocal understanding and 'healthy race-relations'. By means of books, Gladys Oppenheim argues in Books for the Bantu, Europeans acquire 'a knowledge of the Bantu along sociological as well as anthropological lines'. If the African, vis a vis the white reader, is constructed as anthropological curiosity, the reciprocal efforts of reading the 'other' on the part of the African reader are more likely to be framed as duty: 'The Bantu must learn to understand the viewpoint of the White man and so, in turn, learn to express his own attitudes in terms that the latter can understand. ${ }^{15}$ In this asymmetrical model of race relations, the African learns the terms with which to make him/herself intelligible. Also significant in this particular construction of reading is the emphasis placed on African acquiescence, both to an alternative epistemological framework and to the demands of the prevailing socio-political order. In this sense, the liberal race-relations project is figured as a matter of African consent.

As various scholars have argued, the potential benefits (both civic and moral) held out by the prospect of so many African readers was countered by the possibility that reading itself could prove a dangerous force. ${ }^{16}$ In his book The Bantu in the City, American Board Mission representative, Ray Philips laments not only the increasing availability of 'immoral' literature in South Africa but also the greater purchasing power of, and freedom of access amongst, black South Africans. For Philips, the solution lay in controlling the flow of books; that is, of placing 'good Literature before the Location dwellers' as part of the effort to 'inculcate standards of judgement as to what is wholesome and what is less worthy'. ${ }^{17}$

A similar view was articulated by R.H.W. Shepherd, influential editor of South African Outlook and director of the Press at Lovedale College, a major centre for black tertiary

\footnotetext{
${ }^{14}$ Lewis C. Roberts, 'Disciplining and Disinfecting Working-class readers in the Victorian Public Library', Victorian Literature and Culture, 26, 1 (1998), pp. 109.

${ }^{15}$ Gladys Oppenheim, Books for the Bantu: A Study of Library Service for the African, Based on the Negro Library Service of the United States of America, with a Chapter on Bibliotherapy (Pretoria, Carnegie Corporation Visitor's Grant Committee, 1940), pp. 3. Books for the Bantu was a Carnegie-funded study which compared library services for Africans in South Africa with those in the Southern United States.

${ }^{16}$ See for example, Couzens, The New African, pp. 101-102 and Clarke, “"Better Libraries”', p. 25.

${ }^{17}$ Ray Philips, The Bantu in the City: A Study of Cultural Adjustment on the Witwatersrand (Lovedale, Lovedale Press, 1936), p. 313. For background on the American Board Mission and Phillips' social interventions in this context, see Couzens, The New African, pp. 92-97.
} 
education. ${ }^{18}$ The influence of his Christian-liberal assumptions on the question of reading is evident not only in his awareness of the problems of material scarcity and inadequate resources but also in his paternalistic framing of black reading initiatives as a form of 'provision'19 and of the 'European' as avuncular and authoritative guide. In the context of 'onrushing change' and the passing away of traditional modes of being, reading is construed as both a means of cultural adaptation and as recompense for loss. ${ }^{20}$ Like many others who lent support to the liberal library movement, Shepherd worried that the worthwhile efforts of missionary agencies, 'having taught vast numbers to read', might be undermined by the kinds of books which were available. ${ }^{21}$ In this sense, his vision of 'vast numbers of readers' has an ambiguous charge: it raises the spectre of the unruly mob of dubious reason and morality and underscores the need for urgent action. Accordingly, his interventions in the reading debate place emphasis on 'good' or 'worthwhile' literature and privilege a reading disposition of reverence and awe.

In light of the apparent dangers of unregulated reading from a Christian-liberal perspective, the inculcation of the reading habit in the broader project of civility must be accompanied by a careful pedagogy in which readers are instructed in the fine arts of aesthetic and moral discrimination. Important here is the reinforcement of a specific practice of aesthetic judgement derived from a Christian religious framework and rooted in the ethos of the missions. As Philips' comments suggest, the literature that is already regarded as 'good' or morally beneficial begins, in circular fashion, to propose the terms of value by which future books will be judged. In what is also a subtle example of directed reading, canonical literature thus takes on a prohibitive function, encouraging a kind of do-it-yourself censorship. Again, this is not an idiosyncratic gesture of the South African liberal reading project: as Roberts has demonstrated, this notion of readers as passive recipients of the instruction of books, of the books as agents of enlightened change, was also central to advocates of working class reading in Victorian England. ${ }^{22}$

The notion of reading 'unwisely' is given further elucidation in an article in The Bantu World by Edgar Brookes, principle of Adams College and affiliate of the Institute for South African

\footnotetext{
${ }^{18}$ For more on Shepherd, see Couzens, The New African, pp. 102-104.

${ }^{19}$ R.H.W. Shepherd, Literature for the South African Bantu: A Report of a Visit to the United States of America under the auspices of the Visitors' Grants Committee of the Carnegie Corporation (Pretoria, Carnegie Corp, 1936) p. 10.

${ }^{20}$ Shepherd, Literature for the South African Bantu, p. 76.

${ }^{21}$ Ibid., p. 10.

${ }^{22}$ Roberts, 'Disciplining and Disinfecting Working-class Readers', p. 115.
} 
Race Relations. Brookes' definition encompasses not only the problem of immorality but also touches on questions of aesthetics and politics: 'books that are badly written, misleading or foolish'. ${ }^{23}$ Brookes' argument for directed reading includes a warning about 'excessive' reading and the corresponding dangers of solipsism and personal neglect. As illustration, he offers an image of a studious man whose garden is unkempt and whose clothes are stained. Brookes' vignette of inappropriate reading suggests the extent to which liberal reading projects were tied to a broader inculcation of the ideals of middle-class domesticity based on personal hygiene, neatness, moderation and the importance of healthy social contacts. Also at issue is the influence of a Christian moral framework in which reading takes dominant form as duty, work and moral obligation. As in Shepherd's reflections, reading becomes an extension of a reverential spiritual practice demanding the habits of stillness, devotion and sobriety.

The examples presented above testify to the many attempts by liberal advocates to exert control over the potentially wayward effects of readers' encounters with texts - by defining appropriate reading matter, by exerting an influence on interpretation and by offering a model of respectable reading practice and general behaviour. The power of these authorising definitions is underlined by the persistence of a paternalistic, even admonishing, tone arising from the accusation of irresponsibility: despite all the efforts of white philanthropists, Brookes laments, 'some teachers and ministers read next to nothing'. ${ }^{24}$ The absence of reading efforts is construed as wilful refusal, neglect and ingratitude, constituting a breach in the liberal-paternalistic contract. ${ }^{25}$ This notion of contractual obligation goes some way towards elucidating the curious forms of imagined reciprocity or mutuality which colonial and pre-apartheid reading practices engendered in which private and communal acts of reading take place, in part, under the gaze of approving other.

An especially crude illustration of the liberal equation of reading with social control is to be found in some of the earliest editions of The Bantu World. In an effort to encourage new or semi-literate readers of newspapers, The Bantu World included a one-page summary of the most important news items of the week using simple language, bold fonts and generous spacing: 'the object of this supplement', it was asserted, 'is to teach those who cannot read

\footnotetext{
${ }^{23}$ Edgar Brookes, 'Bantu Masses Should Learn to Read Well', The Bantu World (23 July 1932), p. 2.

${ }^{24}$ Edgar Brookes, 'Bantu Masses', The Bantu World (23 July 1932), p.2.

${ }^{25}$ For further examples of this complaint, particularly in relation to teachers, see Peters, The Contribution of the Carnegie Non-European Library Service, pp. 13-14.
} 
and write well in order to make them useful citizens'. ${ }^{26}$ The notion of a useful citizen is given more content in the weeks that followed: without exception, the particular articles chosen for the purposes of reading instruction were those which conveyed a conservative political message. These ranged from the dangers of vice and drink - deemed more harmful to the African than the injustices meted out by 'the white man' ${ }^{27}$ to the importance of public decorum ${ }^{28}$ and the harmful effects of urbanisation: 'The Bantu people who live in rural areas, they say, should be taught to till their lands properly so that there will be no need for them to go to towns where work is no longer available'. ${ }^{29}$ If the newspaper reading scheme was shelved after just a few months, the assumptions that underpinned it continued to be influential. Just beyond the frame of a controlling liberal philanthropy, however, lay the even more prohibitive approach which would assume legitimacy in the apartheid era. This was the stance, summed up at an early library conference, that it would be preferable to 'shoot the Natives rather than give them books to read' and that 'Natives should not be taught to read anything except the Bible'. 30

Early twentieth-century engagements with the question of reading in South Africa alert us to a prevailing reading consensus which is conceived in explicitly utilitarian terms as a form of moral and political instruction - reading as a means of moral and social betterment, reading as an antidote to political radicalism and 'hooliganism' and reading as a means of promoting 'healthy' race relations. Also striking is the proscription on excessive reading, the emphasis on appropriate and inappropriate forms of reading, the importance of directed reading and the encouragement of an appropriate reading habitus marked by devotion, humility and a willingness to be 'worked on' by the book. In a move which quietly disavows their own very obvious investment in the social and personal utility of reading, liberal commentators of the period sought to de-legitimise what they considered to be an overly materialist-utilitarian approach to reading amongst black readers in which reading is seized as a route to material advancement. As one commentator suggested, '[c]ompound and locations inhabitants have not yet reached the stage where they read for pleasure only, or for the purpose of whiling away an idle hour. If the Bantu read at all, they read seriously, they want to study social

\footnotetext{
${ }^{26}$ The Bantu World (31 March 1932), p. 7.

${ }^{27}$ The Bantu World (21 May 1932), p. 5.

${ }^{28}$ The Bantu World (14 May 1932), p. 5.

${ }^{29}$ The Bantu World (28 May 1932), p 5. See also The Bantu World (7 May 1932), p. 5 and The Bantu World (14 May 1932), p.5.

${ }^{30}$ qtd in E.A. Borland, 'Ten Years of the Carnegie Non-European Library, Transvaal: 1931-1941', South African Libraries July, 10, 1 (1942), pp. 1-6. (A paper presented at the Annual General Meeting of the Transvaal Branch of the South African Library Association).
} 
problems, they want to become better educated... ${ }^{31}$ In this evolutionary view of reading, utilitarian reading practices are construed as a developmental phase which will eventually be surpassed. Interestingly, this view was reiterated (word for word) by Carnegie Librarianorganiser, H.I.E. Dhlomo in his 1938 report on the work of the Carnegie library for The South African Oulook. ${ }^{32}$

The emphasis on the transformative power of books and the corresponding focus on separating the 'corn' from the 'chafe' has clear affinities with the preoccupations of the South African Left, suggesting that the public inducement to read is as prominent in schemes of social co-option as it is in projects of radical social change. In this respect, the differences that do exist can be understood as those of content rather than form. Other differences that arise between opposing advocates of the book relate to the broader reading environment and the particular reading habits that are encouraged: where liberal reading projects situate reading and the world of the book in a space beyond the political realm, left-wing intellectuals place emphasis on the political import of the reading context itself; where liberal advocates of the book encourage a reading posture of reverence and awe, those on the Left are more likely to promote the reading habits of scepticism and questioning.

\section{The Idea of Reading in the African Press}

What of the response of African intellectuals as represented in examples of the mainstream and independent press? As suggested above, talk of reading and books in the circles of the African intelligentsia cannot be divorced from the broader social context of racist dehumanisation and exclusion. Explicitly linked to the need to reverse colonial derogation, the preoccupations with literacy and the fostering of a book-reading culture derive not only from the Western privilege granted to reading and literacy as markers of the civilised self but are also related to pragmatic assessments of reading and education as powerful routes to economic and political advancement. In this sense, as Bhekisiswe Peterson argues, literacy becomes 'both the conduit and the sign' of African progress. ${ }^{33}$ As Karin Barber makes clear, the assiduous cultivation of literacy in African contexts, as 'a means of collective and individual betterment' is not an isolated or idiosyncratic phenomenon but rather 'a

\footnotetext{
${ }^{31}$ Carnegie Non-European Library, Transvaal. Second Report 1938.

32 H.I.E. Dhlomo, 'Carnegie Non-European Library, Transvaal', South African Outlook (1 October 1938), pp. 230231. The overt similarities between these two reports could suggest a dutiful mimicry of the prevailing view. ${ }^{33}$ Bhekisiswe Peterson, 'The Bantu World and the World of the Book: Reading, Writing and Enlightenment', in Karin Barber (ed), Africa's Hidden Histories: Everyday Literacy and the Making of the Self (Bloomington and Indianapolis, Indiana University Press, 2006), p. 240.
} 
remarkably consistent and widespread efflorescence - a social phenomenon, happening all over colonial Anglophone Africa at the same time and with comparable features' ${ }^{34}$ This pervasive historical phenomenon, which also extended well beyond the sphere of the educated elite, was also accompanied by acute anxiety, linked to a 'sense of personal inadequacy associated with an education perceived as incomplete'. ${ }^{35}$ Central to these efforts was the claim to modernity, a claim which, as Peterson suggests frequently led to an overstatement of the break with tradition. ${ }^{36}$

Two examples of the popular African press provide one measure of the responses of African intellectuals to the liberal incitements to read during this period. The first, The Bantu World, was a successful commercial newspaper aimed at the urban African market and which formed part of a stable of papers under the white-owned company Bantu Ltd. Edited by R.V. Selope Thema and published weekly, it was by far the most widely-read paper of the period. The second, Inkundla ya Bantu was a rare example in South Africa at the time of an independently-owned and run African paper in which the editorial consensus favoured more outspoken and critical forms of expression than those that characterised the moderate commercial press. Originally published as The Territorial Magazine, Inkundla ya Bantu was produced in Verulum, near Durban, under the editorship of Philip Goduka Katamzi. In 1944, Jordan Ngubane took over as editor until the paper's demise in $1951 .^{37}$

Peterson's study of African reading practices as reflected in The Bantu World draws attention to the importance placed on 'ritualised' daily reading (an emphasis which conflates reading with middle-class domesticity) and the perceived links between an habituated literacy and the emergence of African-authored texts - regarded by many amongst the African elite as an urgent political project. ${ }^{38}$ As in other contexts, these early articulations of the reading and book debate - evident across a range of texts including editorials, reports and letters to the

\footnotetext{
${ }^{34}$ Karin Barber, (ed), Africa's Hidden Histories: Everyday Literacy and the Making of the Self (Bloomington and Indianapolis, Indiana University Press, 2006), p. 3.

35 Ibid., p. 5.

${ }^{36}$ Peterson, 'The Bantu World and the World of the Book', p. 239.

${ }^{37}$ For more details, see Les Switzer and Donna Switzer, The Black Press in South Africa and Lesotho: A Descriptive Bibliographic Guide to African, Coloured and Indian Newspapers, Newsletters and Magazines, 18361976 (Boston, Hall, 1979). For more on The Bantu World, see Couzens, 'A Short History of the "The World" (and Other Black South African Newspapers'), African Studies Seminar Paper (June 1976), pp. 1-26 and Les Switzer, 'Bantu World and the Origins of a Captive African Commercial Press in South Africa', Journal of Southern African Studies, 14, 3 (April 1988), pp. 351-370. On Inkundla ya Bantu specifically, see Ime Ukpanah, The Long Road to Freedom: Inkundla ya Bantu (Bantu Forum) and the African Nationalist Movement in South Africa, 1938-1951 (Trenton, New Jersey, African World Press Inc, 2005).

${ }^{38}$ Peterson, 'The Bantu World and the World of the Book', p. 240.
} 
editor - reading is posited as a form of personal and material advancement and a means of instruction and self-improvement in the context of dizzying social change. As one commentator suggests, it was a means whereby 'a youth with high ideas of selfimprovement' can make himself into 'a perfect man of tomorrow'. 39 The claims to reading asserted here, unlike many of the workers' reading initiatives in Victorian Britain, are framed not as a right to knowledge against the vested interests of the powerful; ${ }^{40}$ rather what is invoked is an older form of colonial-developmental discourse marked by the watchwords of 'civilisation', 'awakening', 'betterment', 'regeneration' and 'improvability' and the corresponding assumptions of 'lethargy' and backwardness. ${ }^{41}$ It was in relation to this set of ideas that The Bantu World positioned its own efforts to stimulate the 'love for reading' amongst Africans. $^{42}$

In a context in which history is understood as 'moral progress', ${ }^{43}$ anxieties about non-readers and inappropriate reading are likely to be particularly acute. Echoing the styles of liberal authority, the numerous incitements to read in The Bantu World tend to take the form of exhortation which invariably shades into moral rebuke. Numerous articles and letters take up the project of reading evangelism, one which not only articulates considerable consternation at the absence of reading amongst Africans but also gives details of its innumerable consequences and benefits. ${ }^{44}$ An oft-repeated concern about those who are unable to see the profit of reading is also accompanied by strictures on unacceptable reading practices such as reading 'only to pass the time' or reading as a form of ostentatious display. ${ }^{45}$ The emphasis placed on the serious and focused links to other anxieties about 'useful engagements' and the 'proper use of time'. ${ }^{46}$

Further echoes or reiterations of the dominant liberal view are also to be found in the widespread construction of reading as a mitigating force in relation to 'crime and hooliganism in the locations ${ }^{, 47}$ and of reading as a means of '[helping] to make Natives law-

\footnotetext{
${ }^{39}$ S.A. Malao, Letter to the Editor, 'The Pleasures of Reading', The Bantu World (3 August 1935), p. 8.

${ }^{40}$ Jonathan Rose, The Intellectual Life of the British Working Classes (New Haven, CT, Yale University Press, 2001), p. 64.

${ }^{41}$ For representative examples, see The Bantu World (30 December 1933), p. 1; The Bantu World (8 January 1937), p. 8 and Ilanga Lase Natal (19 June 1943), p.8.

${ }^{42}$ The Bantu World (14 April 1934), p. 1.

${ }^{43}$ Peterson, 'The Bantu World and the World of the Book', p. 245.

${ }^{44}$ See for instance, Joe J. Maholla, 'The Value of Reading', The Bantu World (29 July 1938), p.5 and 'Those who do not Read "The Bantu World"', The Bantu World (18 March 1939), p.12.

${ }^{45}$ The Bantu World (7 August 1937), p. 16.

${ }^{46}$ The Bantu World (25 December 1937), p. 16.

${ }^{47}$ The Bantu World (22 May 1937), p. 8.
} 
abiding citizens'. ${ }^{48}$ The particular register of compliance inscribed in these and other examples is also indicated in the avoidance of political critique - in the fact that the social evils that the writers deplore are attributed not to a particular set of social practices deriving from the policy of racial segregation but rather to 'the diseases of an ignorant society' thus giving further impetus to assumptions of African inadequacy. ${ }^{49} \mathrm{~A}$ similar kind of disavowal is to be found in the argument that '[m]ost of our ills and disasters spring from the existence of illiterate, blind, emotion-controlled masses who cannot read and reason for themselves and who are fertile ground for the doctrines of political demagogues and chauvinists'. ${ }^{50}$ In this context, reading and literacy are explicitly deployed as a means of emancipating the race from the 'slavery of ignorance'. ${ }^{51}$ What is articulated here is a common conflation of illiteracy with both irrationality and the absence of knowledge. Also important, in the early years of World War II, is the inclusion of the rhetoric of demagogues within the category of dangerous texts, a view which was also echoed by white liberals. ${ }^{52}$

The liberal race-relations ethos is also a significant influence in the on-going reading debate in The Bantu World. This is suggested in the popular understanding of reading as a means of promoting 'healthy contacts between Black and White' and in the notion that literature can assist in the negotiation of social difference - 'people other than ourselves'. ${ }^{53}$ As in the liberal-philanthropic view, reciprocal duties are clearly differentiated along racial lines with the burden of understanding and acceptance placed on Africans and the corresponding duty of sympathy conferred on whites. As one writer suggests, '[t]he library is doing good work for it is helping the Native to understand the white man's point of view and the white man to be more sympathetic to the Native'. ${ }^{54}$

Also in line with the liberal view, the moral imperatives of reading take foremost place. This is evident in a widespread concern with immorality and 'good' literature but also, as Peterson argues, in the predominance of Christian tropes of journeying and redemption. In this perspective, librarians become a species of evangelists in a common moral project of 'schooling' the race. Questions of duty, obligation and service are also evident in more

\footnotetext{
${ }^{48}$ The Bantu World (8 January 1937), p. 8. See also The Bantu World (27 August 1936), p. 4.

${ }^{49}$ The Bantu World (27 August 1938), p. 4.

${ }^{50}$ The Bantu World (7 December 1940), p. 4.

${ }^{51}$ The Bantu World (16 July 1932), p. 1.

${ }^{52}$ See, for example, 'Transvaal Carnegie Non-European Library: Memorandum on Library Services for the Bantu People of the Union of South Africa' (April 1949), p. 5. South African Institute of Race Relations (SAIRR), 18921974. AD1715. Historical Papers Research Archive, Johannesburg.

${ }^{53}$ The Bantu World (1 October 1932), p. 6.

${ }^{54}$ The Bantu World (9 March 1935), p. 5.
} 
general attitudes towards the 'gifted Bantu' and their unique responsibilities in relation to their 'unfortunate and unenlightened people'. 55 The pervasive tone of compliant acceptance articulating a Christian moral world view is underscored by the particular praise reserved for the powerful figure of the white patron: those 'men who have given themselves wholeheartedly for Bantu welfare'. ${ }^{56}$ Whatever the role of strategic mimicry in these texts, what is nevertheless clearly affirmed is a construction of reading and librarianship as essential moral projects in the betterment of the race.

Women readers of The Bantu World are particular targets of the morality of the book and repeatedly advised about the dangers of 'trashy books' and the 'mischief of bad reading'. ${ }^{57}$ Articles such as these, however, offer a rare acknowledgment of the existence of the woman reader and the role that the newspaper paid in women's lives. This recognition may well have been prompted by a letter to the Editor written in 1932 by '(Miss) Gladys Ramokweni':

I am one of the lady readers of 'The Bantu World' and have found the paper so interesting that I hope it will live for ever. I do not know if you have women subscribers; but judging from the fact that there is hardly any article by a woman I have concluded that there are few women readers of your valuable paper. ${ }^{58}$

The burden of the letter is not to judge the paper but to encourage women to 'cultivate the habit of reading books and newspapers so as to keep abreast with the times'. ${ }^{59}$ The difficulties involved in a woman's claim to reading are apparent in the oscillations of the text. An argument for greater access and participation as a means of adapting to a rapidly changing world shades into a position in which this newly acquired knowledge is put into the service of conservative definitions of wifely duty, the parameters of which are in the process of being redefined. What is required of the emergent role of 'help-mate' rather than 'servant' is an understanding of 'the multifarious duties' and forms of understanding which go along with the modern wifely role. ${ }^{60}$

The paper responded not with a raft of new female journalists but rather with a women's page, a not unexpected decision reflecting both the rarity of educated African women and the

\footnotetext{
${ }^{55}$ The Bantu World (21 May 1932), p. 2. See also The Bantu World (16 July 1932), p. 1.

${ }^{56}$ Ilanga Lase Natal (26 April 1941), p. 3. See also The Bantu World (27 August 1938), p. 4 and The Bantu World (7 December 1940), p. 4.

${ }^{57}$ 'Never Read a Bad Book', The Bantu World (6 January 1940), p. 8.

${ }^{58}$ Gladys Ramokweni, 'Women and Newspapers', Letter to the Editor, The Bantu World (30 July 1932), p. 4.

${ }^{59}$ Ibid.

${ }^{60}$ Ibid.
} 
traditionally demarcated gender divisions of the period. What is striking about these pages dedicated to the fostering of a moral and domesticated femininity and replete with stereotypical assumptions - is the recognition they afford to the category of the woman reader, of the women as reader who is frequently addressed in precisely those terms. An article by Johannah Phahlane which appeared two years later is noticeably less responsive to the need to offer conservative rationalisations in the making of emancipatory claims. In this case, reading is constructed in terms of the serious and productive, a pastime which 'yields returns' and adds to your 'stock'. The notion of reading as sound financial investment is also accompanied by an unusual claim for extensive, even indiscriminate, reading: 'Time will teach you, as it taught Sir Walter Scott, to despise no scrap of knowledge, however obtained'. ${ }^{61}$ That reading for women in particular continued to be regarded as an index of decorous femininity is suggested in a letter from Rahab S. Petje entitled 'Books as Companions'. In the spirit of the genre of women's advice columns which dominates the women's page in The Bantu World, readers are advised to turn to books in times of need:

If perchance you have had a clash with your friend, get a good book from your collection and sit by the fireside or lie down in bed and there and then you will find consolation. ... For instance, when you have been jilted don't read Shakespeare's 'Twelfth Night' where Orsino sings a dirge just because he had been jilted, but read R.L. Stevenson and Longfellow who tell of struggles in life and toleration during temptation and the beauty and joy of living in spite of hardships. So rather be gregarious with books than with human friends for they make a louder noise than an empty tin, and you are always in fear of losing them. ${ }^{62}$

Aside from the kind of books which are included, the aesthetic distinctions which are made, and the assumptions about reading contexts and possessions which are encoded ('firesides' and 'collections'), what is also interesting here is the extent to which the book is advanced as companion and friend. This anthropomorphic framing of books is also evident in an article written in Ilanga lase Natal by R.R.R. Dhlomo. ${ }^{63}$ Working within the

\footnotetext{
${ }^{61}$ Johannah G. Phahlane, 'Bantu Women Should Try to Encourage Each Other to Read', Letter to the Editor, The Bantu World (12 May 1934), p. 12.

${ }^{62}$ Rahab S. Petje, 'Books as Companions', Letter to the Editor, The Bantu World (3 October 1942), p. 8.

${ }^{63}$ Founded by John Dube, Ilanga lase Natal started out as an independent paper but was subject to increasing control by Bantu Press from the mid-1930s onwards, an organisational change which was also reflected in its increasingly moderate stance. Notable editors of the paper included Ngazana Luthili (1915-1943) and R.R.R. Dhlomo (1943-1962). For more information, see Les Switzer and Donna Switzer, The Black Press in South Africa
} 
reigning paradigm of books as treasure stores of wisdom, a 'store of goodly thoughts in well-wrought words', Dhlomo expresses his regret that so few of his readers 'have brought themselves up on the milk of book-reading and book-worshipping' ${ }^{64}$ If the attitude of reverence is unmistakable, so too is the particular intimacy of the book reading experience - powerfully inscribed through the metaphor of breast-feeding - in which the mother is replaced by the book. The anthropomorphic register continues in the references to succour, inspiration and solace as it does in the emphasis placed on a democratic ethos: in a move that echoes W.E.B. Du Bois's oft-cited formulation, Dhlomo imagines an egalitarian book that makes no distinction between person of differing social ranks: 'its good is not reserved for its master only; it imparts light and understanding to all who have the courage to open its doors and be received into its comforting arms'. ${ }^{65}$

If the liberal-Christian assumptions of the 'Non-European Library Movement' can be seen to permeate the debates about reading in The Bantu World and other moderate African newspapers, if they to some extent provide the terms in which the subject of reading is broached and understood, there is also evidence of a countervailing view, one which works by implication rather than direct statement. Dhlomo's intimations of democracy provide one such example as do the scattered, mostly tentative references to the wider social context of institutionalised inequality and deprivation, such as the high cost of books, the problems of widespread illiteracy and the daily experience of hardship and material constraint. As Geo Francis Khumalo puts it, 'Life's worries causes mind wandering and soon they forget what they have read before they use it' ${ }^{66}$ Perhaps in deference to the prevailing distinction accorded to non-utilitarian reading, S.A. Malao writes earnestly about the joys of reading as a form of refreshment and escape. In this instance, the reading of literature is conceived in spatial terms as a 'field of forgetfulness' an open, expansive space conducive to leisurely, even desultory, rambling: it is a 'square field of happiness where a person of high educational opinions and intellectual tastes can roam enough to reap what has been sown'. ${ }^{67}$ The many images of roaming, tasting and savouring in this article form a striking contrast to the Christian-liberal emphasis on productive reading practices and the proper use of time. Again however, Malao's vision of non-productive, meandering pleasure is partly undone by an ideal

and Lesotho: A Descriptive Bibliographic Guide to African, Coloured and Indian Newspapers, Newsletters and Magazines, 1836-1976 (Boston, Hall, 1979). pp. 38-39.

${ }^{64}$ R.R.R. Dhlomo, 'Books', Ilanga Lase Natal (2 October 1931), p. 8.

${ }^{65} \mathrm{lbid}$. The text to which Dhlomo alludes is W.E.B. Du Bois' The Souls of Black Folk, (London, Constable, 1905).

${ }^{66}$ Geo Francis Khumalo, 'A Plea for Literary Clubs', Letter to the Editor, The Bantu World (7 August 1937), p. 16.

${ }^{67}$ S.A. Malao, 'The Pleasures of Reading', Letter to the Editor, The Bantu World (3 August 1935), p. 8. 
of middle-class domestic gentility in which the practice of reading is rendered as a powerful anchoring force in the attainment of a sober, ordered and harmonious domestic life: in this view, literature becomes an important contributor to 'the harmony and peace factor of any civil home'. ${ }^{6}$

A further example also alludes to a broader social context of systematic deprivation and difficulty through oscillating ideas of the joys of physical gratification, the pain of hunger and the promise of relief. According to this writer, libraries are 'an extensive orchard where one may pick delicious gems and appease [one's] hunger'. The possibilities and pathos of hungering and finding help are given added emphasis through the interpolation of the Biblical verse of Isaiah 55: 1-4:

Therefore like the prophet we invite our thirsting people to 'come and eat; yea, come buy wine and without money and without price. Wherefore do ye spend money for that which is not bread? And you labour for that which satisfieth not?'69

As in Dhlomo's article, images of succour and salvation offer an implied critique of conditions of material constraint, a critique that is also partly undone by the standard gesture of moral rebuke contained in the final lines. Examples such as these elucidate not only the difficulties of articulating dissent in white-sponsored public forums but also the importance of Christian religious frameworks as a means of making sense of reading practices amongst an urban African elite. With regard to the latter in particular, what is also suggested is their complex undecidability - the way in which they encompass both the emancipatory promise of salvation and the obligations and prohibitions of Christian morality.

The subject of reading also figures prominently in the pages of the independent African monthly, Inkundla ya Bantu. As in the more moderate papers, traces of a conservative position are evident in the conflation of literacy and reading with 'civilisation', ${ }^{70}$ in the notion of reading as a 'developing the spirit of service in young Africans" ${ }^{, 71}$ and in the continued deployment of the framework of racial advancement. An argument in which illiteracy is described as a threatening dragon which needs to be slayed invokes the spectre of racial degeneracy and regression and of Africans as a 'cindarella race', left behind in the universal

\footnotetext{
${ }^{68}$ Ibid.

${ }^{69}$ The Bantu World (27 August 1938), p. 4.

${ }^{70}$ Inkundla ya Bantu (July 1941), p. 1.

${ }^{71}$ Inkundla ya Bantu (June 1941), p. 5.
} 
march of progress. ${ }^{72}$ Like The Bantu World, the newspaper expressed considerable anxiety about the absence of a reading culture amongst Africans - even those who can read do not read, do not patronise libraries and do not buy books. If the shades of an earlier discourse of civility are still in evidence, what is also discernible is an understanding of literacy as a fundamental component of modernity and, as such, both indispensable and irresistible: '[The] reading public is growing, for it is being swept forward to the future by the tide of economics as well as by the tide of education. No political King Canute can reverse these tides'. ${ }^{73}$

Inkundla ya Bantu gives far greater significance than either The Bantu World or Ilanga lase Natal to the impact of structural inequality and offers an understanding of South African reading cultures in the context of material scarcity, high rates of illiteracy and the absence of compulsory education. In this way, liberal arguments centred on individual improvement, always darkened by reproach, are articulated in tension with those which call for organised, collective political action in the form of an ANC-led mass literacy campaigns and other forms of associational support such as night schools, study groups and reading circles. In addition, against the image of the book as fetish comes a pointed argument about the limits of reading and education in contexts of institutionalised racism and inequality. In a 1941 editorial, for example, Francis Bacon's famous dictum is rewritten as 'Reading alone does not make a full man. Man has to eat to live. It is eating rather than reading matter that is fundamental to the existence of man'. ${ }^{74}$ The stark opposition between 'eating' and 'reading' draws attention to the material constraints of structural unemployment, poverty and job reservation, conditions which place a bar on opportunity no matter how much reading is achieved. In such contexts, the writer suggests, the benefits of reading and education can only be class-specific, reserved for a few whose own life chances will be substantially improved. If educated elites are warned about ignoring their positions of relative privilege, they are also alerted to the ways in which reading and education projects form part of the instrumentalities of oppression: 'To be approved by dominant South Africa, Native education must fit the Native ever to become the servant of the white man'. 75

That the world of the book becomes a far more politicised terrain in this newspaper is also evident in widespread debates about the politics of representation in the context of school and child reading - in particular, the 'biased writing of Europeans who applied European

\footnotetext{
72 Inkundla ya Bantu (November 1945), p. 2.

${ }^{73}$ Inkundla ya Bantu (September 1946), p. 2.

${ }^{74}$ Inkundla ya Bantu (September 1941), p. 2.

${ }^{75}$ Ibid.
} 
standards to judge African conditions' ${ }^{76}$ In this context, the notion of reading as hazardous activity takes on an entirely different significance as various commentators point to the problems of historical distortion, stereotyping and inaccuracy. Here the dangers of reading are both psychological and political, inducing resignation and acquiescence. As the writer goes on to explain, 'Even in schools this insidious propaganda makes the African child think Wallet Vilakazi a clumsy dwarf by the side of Shakespeare. In fact the African child does not believe that there is anything worthwhile that Vilakazi can do since Shakespeare, Racine, Tolstoy etc. did all there was to do in Literature'. ${ }^{77}$ The privileged reader in these scenarios is the young black child reading his/her school books, an innocent imbibing damaging and historically inaccurate views. As another commentator suggests, these books 'prepare the African for an inferior type of citizenship'. ${ }^{78}$

What is particularly striking here is the extent to which the broader reading project in early apartheid South Africa founders on the absence of suitable books. In this sense, Inkundla's critique of historical misrepresentation (and unequal citizenship) points to an unusual problem in a general history of reading, namely the book which is absent or not-yet-available - the anticipated book of the future. What ensues is an oft-repeated emphasis on African authorship and the notion of an 'African interpretation of events' and the need to rewrite history from an 'African perspective', arguments which easily segue into an essentialist stance. In contrast to earlier constructions of the grateful recipients of white patronage, furthermore, what emerges in these reading contexts is an image of greater agency. But 'Twana' is still despairing: 'our chief weakness is that we allow ourselves to be misunderstood or misrepresented. We are too dumb for Civilisation - thereby paving the way for our enslavement'. ${ }^{79}$

The remnants of a lively reading debate amongst African intellectuals in early twentiethcentury South Africa point to three distinct patterns of response in relation to the liberal incitement to read. First, what is suggested is the profound influence of the liberal reading consensus in establishing the terms of black reading encounters during this period, one in

\footnotetext{
76 'Twana', 'A Nation Building Itself', Inkundla ya Bantu (September 1943), p. 2. A similar view, if more moderately expressed, is to be found in an article in Ilanga Lase Natal by 'Busy-Bee', a pseudonym for H.I.E. Dhlomo (8 January 1944), p. 8.

77 Ibid., p. 2.

78 Inkundla ya Bantu (May 1946), p. 2.

79 'Twana', 'A Nation Building Itself', Inkundla ya Bantu (September 1943), p. 2.
} 
which the moral and civilizational imperatives of the liberal reading project take central place. Within this prevailing consensus, women are particular targets for the morality of the book. What is also discernible, however, are those responses to the liberal consensus which oscillate between the incompatible registers of compliance and critique, reiteration and departure, mimicry and resistance. What is in evidence here is a subtle to-and-fro movement in which the dictates of the liberal perspective are both accepted and tactically undermined. Both of the above responses on the part of African readers pose problems for an overly dualistic or oppositional scheme of 'readers versus institutions', suggesting a more complex, more ambivalent and more mobile engagement. What might be identified as a third pattern of response, however, is one in which the prevailing reading consensus is increasingly placed under question, particularly through the attention given to the limits of reading and the absence of books. Especially important here are those arguments which situate the topic of South African reading cultures within the context of material scarcity, as well as those which place emphasis on the political import of reading and the politics of representation. From a general interest in reading from the late 1930s onwards, one discerns a noticeable shift towards a more vociferous and more self-conscious engagement with the social and political importance of reading and what is being read. What is indicated here, I would argue, is the extent to which the world of the book in the pre- and early apartheid contexts is increasingly understood in politicised terms, as a reflection of a larger context of discrimination and disempowerment. This, along with the evidence of an increasingly sceptical stance, points to a significant overlap between the views of African intellectuals in the popular press and those which are conventionally associated with the South African Left. 